稚

\begin{tabular}{llll}
\hline 外 國 綶 報 \\
\hline
\end{tabular}

加奈陀，日本及満洲國よりの輸入禁止9月23日附總督命を ®以て，カナダ政府は特に國稅大臣の許可があつを場合の外は，山本及 滿洲國生產品並に日㴖兩國からの輸运に係る物品の蝓入を禁止した 旨, 9 月 25 日附國稅行「メモランダム」を以て同月 27 日公表した。 右に付外務少保官は當館員の質閔に對して，先般公布せられた資济涷 結令の赛施に依り，既に本邦品は全然湙入が不可能々なつて居る次第 であるが，右凍結令關係括项は從來外國䉆替管理局の主管に屬して居

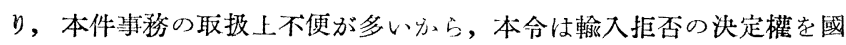
稅大臣に移管することを主眼とするものであるとの趣旨を語つた由で ある. (9 月 30 日着, 在カナ分, 吉澤公使電報)

外務省通商局日瓡 (昭 16.10 .3 )

エヂプト政府輸入制限惯施エヂプト政府は軍需品に對する船 腹を磪保し，且つ包需品の輸入を制限する目的を以て，新に輸入制限 措置を赛施したが, 是に依礼ば 1941 年 10 月 1 日上り 1942 年 4 月 30 日に至る牛ヶ年間に於ける民需品に對する輸入總許可量は 244,920

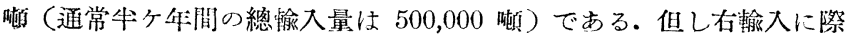

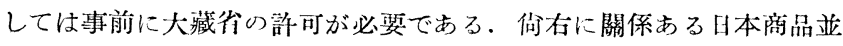
にその制限數量は次の通りである.

\begin{tabular}{|c|c|c|c|c|c|c|}
\hline \multicolumn{3}{|c|}{1 七 } & 各 400 & 顿! & 〔人絹絲 & 180 \\
\hline & 絹 & 絲 & 600 & " & 綿 絲 & 500 \\
\hline & 煙 & 草 & 2,400 & " & 茶 & 3,000 \\
\hline & 綿 & 乍 & 3,000 & " & & \\
\hline
\end{tabular}

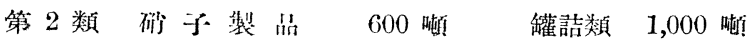

(10月 3 日在埃, 鈴木公使電報)

外務省通商局日哌 (昭16.10.6)

佛印硅砂再輸入このほど日佛印间に交涉纆り，佛印硅砂の再輸 入を開始することになつた。

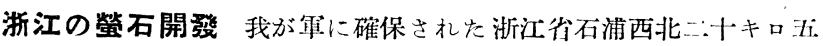

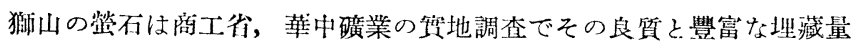
が確認され近く華中斜業の手により探掘されること〉なつたので探掘 現場から山麓への道路と山麓から海岸へのトラック道路工事が開始さ れた。

同鐄區は可探鍰量三十萬卜シ，然際は六十萬トン以上もあり，本均

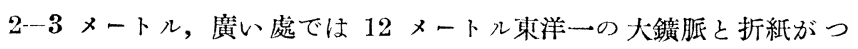
けられ炎。

石岩の新採掘法 强力な貲射水を炭㕌一连入して石炭を破碎し, 之をその水流で別の川から地上一欣き上げ樣と云ふ企てがン聯で行は れて居る. 大體の豫備赛驗を終つて目下年:座 10 萬顿の設備名建設中

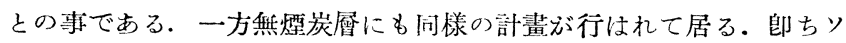
聯邦石炭工業委員會では之等の結果を見た上でドネックズネッッ及び ウラル地方に 10 乃至 12 ケ所に大規模の水力探炭坑を設ける豫定で あると.

$$
\text { 内 國 巢 報 }
$$

全日本科學技術團體標蕉用語整備委員會 10 月 8 日正个よ
り神田逞鍗町 1 の 2 全科技聯會議室に於て第 6 專門委員會 (化學) の第 1 四委員會を全科技聯井上專務理事，企基院鈴江技師出席の下に 開催し，本會よりは委員未定の舀，代理として福团事務員出席す。下 記の姆き方針說明あり。

1. 資源に關する標準用語の整徣は企眐院第 7 部之を擔當す。

2. 企畫院は標準用話の原案作成を全科技聯改科學動員協會に委喝 t.

3. 關係各聽は用語原の作成審議に付緊密なる連絡を保つものとす. 4. 標準用語案は閣議決定を經て之を内閣より公布す。

原案作成要領に關し說明ありてその時期は昭和 17 年度末を豫定し 沃定後は補遗委員會を全科技聯に永續的に存置する、科學動員脇會は 標潐用嗐集の編纂及刊行を擔當す。

第 6 專門委員會は日本化學會, 工業化學會, 本會及び日本藥學會が 主となりて進行する事に決定した。午後 2 時牛散會.

退藏理化學機械に動員炃 金屬類の使用制限强化によつて一般機 械類ひ製作は非常な蜼關に直面してるるが一方この使用制限の飛つち りを受けて理化學器械類の製作も鬼㑇劕滑を缺く憾みあり, これがた め切觕の高度國防國家の建設に不可缺な科學研究に支障を來たすの で，交部行科學課ではこれが對策を考究中のところ，ての注ど全國各 人學，占專等の研究施設中で退藏されてるる器峨類を動員し，己れを 付無呅流せしめて活用を圆ることに方針一決，既にこの調查表を作製 して關倸方面に配布協力を求めてるる。

即ち右の退藏器械類はレンズ, メーター等の部分品となつたもの を子含队その規格, 性能, 容量, 附屬品名, 所在, 製作會社名, 購 入年月日，傊格，過去の用途，修理を要する箇所，その概算費用， 保管轉換の能否條件, 其場使用の可否條件等詳細に亘つて調查し, 文現在使用中のものに就ても同樣調查するもので, この部面ではミ クロトーム, 倍率下以上の顯微鏡, 容量 10 分の 1 ミリグラム以上 い天科，F 1.5 以上けレンズ, スペクトロスコープ, 畺空管, 時覞 门圆以上のメーター類, 其他裝置類に關しては恒溫空, 低厘及び高

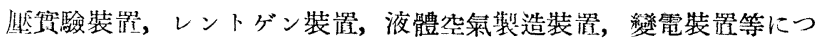
いても箅查して罱き萬一に備一んとしてるる。

而して右調查は退藏中のものは10月末までに, 現在使用中のものは ナ:ン月までに調查を完了しててれを集計整埋印刷に附したる後, 再び 各校宛配布して所斯の目的に添はしめんとしてをり又調查も一年每に 更新したき方針であるが，これが交流利用に當つての交涉は當該學校 間，或は研究所間にて行ふととになつてるる.

東エ大・學科課程を刷新 東京工業大學では輓迍の獨創的科學技 術の磪立と，これによる我國座業技術の飛躍的發展を要望される析柄 これが涬成には學科課程の改正こそ第一要件なりとし先學期末に基本 要綱を確定するとともに, これが立案委員會を設け, 以來數十包に互 る研究討議を重㸚つつあつたが，乙のほど大體の方針を決定した模樣 である、郎ちそれによると

1. 杽生の自發的學修の必要を重要視し，これが獎勵のため演㕷を 擴大し，基礎的諸學科目を充分體得せしぬる。

2. 自主的選擇の範圍を廣くし，將來新生面を開拓するに必要な素 質学養子。

3. 健康狀態に留意し，更に進んでこれが强化向上を計る.

4. 现在の學㕷と各種修練との間の時間的相古を回避するため, 請 
義時間を炳縮して涂睱を大ならしめる。

等であつて，ての線に沿つて新學科課程の具體策が樹立されるものと 見られてをり，具體策作线次第文部省儿認可申請を行ふ豫定である。

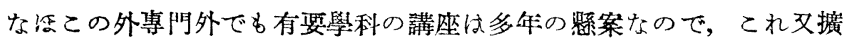
充强化されるものと㿞想されてるる。

重石・雲母・螢石に增産助成金 朝魚總督府では重要鐄物たる夕

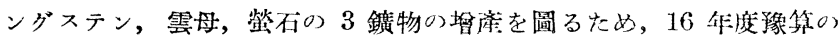

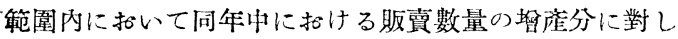

1. タングステン鑛 1 迪につき 375 圆以內.

2. 雲母（雲母配給調整規則に定むる雲母に限る）1酎につき 1500 圆以内.

3. 䈍石（弗化カルシウムの)含有量 100 分の 93 以上のものに限 り) 1 酝儿つき 30 回以內。

の助成金を交附すること〉なつたが，右助成金の交附受付は去る 9 月 30 日で締切った。

日陶聯斯業新體制協議川陶聯では陶磁器工業臨戰體制整備の なめ去る 10 月 4 日總代會堂開催し全役貝の總改選を行つたが, これ に先立古本年度下牛期（10 月- - 3 月）の石炭割當が決定し，上牛期に 比し幾分の制減を見炕ので、本年 8 月以來赛行に移しつ〉あつた從 來の計畫生產を改廢して新に石炭の需給狀態と相俟つて計语生産を再 建すへく，10月3 I商_工行關保官臨席の下に日陶聯事務局首腦部之の 間に於て計畫生產の協詵学行ひ，更に準備中の企業整備問題に關して 再檢討した。

陶磁器試驗所第四部を設置商工行陶磁器試驗所では今包第 4

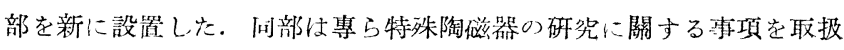
ふ箱で部長は當分秋月所長が策任する模樣である。

陶磁器官民協議會 全國陶磁器卸聯盟では, 陶磁器配給機㴕整 俏要項に基き下部機構の組織化の促進に努めて來たが，てれが筼行に 當り細部に砍義を生ずるに至つたので，去る 10 月 13 日午後 1 時牛ょ り東京市丸, 內糖業會館に於て商工少係官, 聯盟乘下儿地區の幹事並 びに, 地區業者代表中部 (愛知) 大岛, 横田, 北陸 (石川) 園, 在田 近畿（大阪）阴坂，奥村，中國（阔山）會田，佐藤，四國（香川）長 野, 阙野, 儿州 (福弣) 鶴, 廣瀨等十俆名出席し, 協議會を開催, 商 工省商務課より當局の趣旨を說明，次いで条業者代表より

組合員の資格, 烸商聯結成, 京都振興會社, 需給協議會, 代行手數

料, 荷作運貢, 利澗配分率, 聯盟結成, 企業整備 等に就き常局側の說明を求め，種々意見を交换した結果丽者閌に大體 意見の一致を見た。な活こ礼に上つて去るし月以來照案となってる た機構整備問題子愈子新發足すること〉なつた。

代用品協會霓知支部陶業統合につき具申商工行で目下 企畫中の陶磁器工業整储要綱は，地域的企業合门间計㱬の方針の下に整 備されつ〉かるが，右に對し代用品協會愛知縣支部ではこれが施行に 常り，その影響の重大性特に金屬代用品製造の時局性と，これが新興 工業としての特殊性'鑑み，未だ發展途上にある斯業をしで從來の如 き一般陶磁器工業々问一視し，乙れをその埰内に於いて整備せんとす ることは，斯業の將來性を阻害するものとして，去る 24 日陶磁器製 品部會を開催し，て金屬代用品陶磁器工業の企業合问に關し，當局一具 申の件につき種々協議を行つた。

珐瑯界の整備要網通牒珪瑯鐵器界の企業整備に就ては業者間
で自主的にこれを推進せしめつつあつたが，7・7 禁令の强化により一 頓挫を來茫してるをところ，商工少ではこの结どこれが企業整借に關

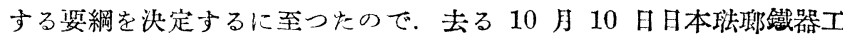
業組合聯合會理事長に對し硋㴗綱に基く惯施案の作成を命ずると同時

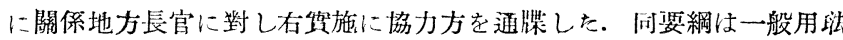

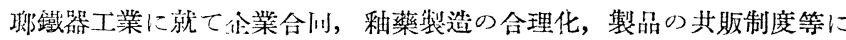
關方る根方本針を磪立し，化學用珐坜鐵器工業に就て结企業合问の力

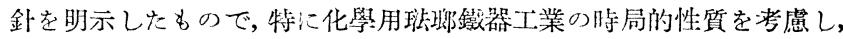
その企業合同には生產性の昂揚が企圖されてるる。

\section{$\diamond$ 一般用理菂鐵器工業整備方針}

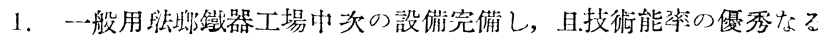
工場を選定し，これを中心として企業の合问をなさしむること

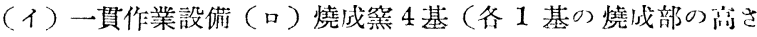
2 大以上,幅 4 爬以上，奥行 4 尺以上）

2. 企業合阔は專ら中心工場に生產を集中するとと

3. 企業合闹體の組織は商法上の會社又は有限會社とするとと

4. 中心工場の選定及び企業合同の貫施は商工行並びに地方聽指尊 の下に企業整供委貝會をして之をなさしむること，委員會は商 工行指名す

5. 遊休設備は國民更生金庫をして引受けしむること

6. 完全に轉殿業する事業主に對し，企業合问體をして共助の途を 講ぜしむるとと

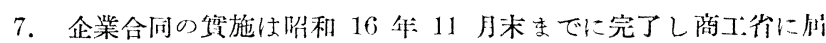
出しむること

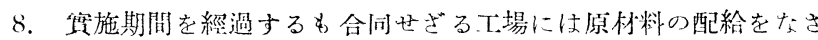
ざること

9. 嬏藥の製造を目的とする新會神を設站しその工場に生産を菜中 すること

10. 製品の一元的共販會於を設立するとと

11。既存の工業組合及び间聯合會は解散し全國單一工業組合を設立 せしむること

$\diamond$ 化學用扯琪鐵器工業整備方針

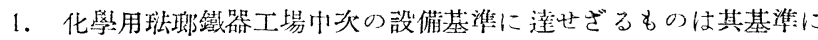
洼する如く企業の合同をなさしむること（イ）一貫作業設噺を

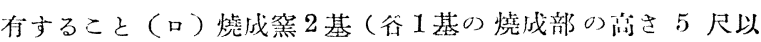
上，幅 4 个以上，奥行 7 ค以上) 以上を存すること

2. 企業合同の組織體，洔斯，一般企業合间をなさざるものに對す る掑置等は一般用に準ずる

3.一般用業者とともに全國單一工業組合を設立せしむるとと

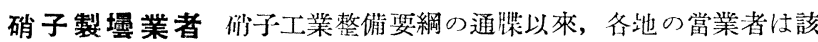
装綱に基き着々企業の整理統合を急いてでるるが，大阪に於ける斯業の 大牛は製琴業者で占めて居るので，乙れが統合は至難なものがあり， 颇るその動向を注視されてるる。

基间傳一られる所に依ると，矿了製埪業者の内白動製摆機を存する 業者は極く僅かで，自動製照業者は各自獨立に運營を汁り年自動製 恣業者は各業種别に合间體を組織するのでないかと胃られる。 一方，斯業に對する下牛期の曹涬灰の制常曼は上牛期のそれに比し 4 割 5 分の激減を見てるるので、速か心整僻し合理的運管を神る心くく价 方面から待望されてみる。 